ISSN 2358-6060

DOI: https://doi.org/10.5216/ac.v6i2.65093

\title{
Sebastião Silva*
}

Lara Rodrigues Machado**

Wanças, Poéticas e os Oaberes Corporificados

Dances, OPoticsn And Corporate Ynowledge 


\section{RESUMO}

A narrativa poética de Lara Rodrigues Machado e Sebastião Silva oferece as leitoras e leitores histórias de experiências da vida e ou da cena que se desdobram por meio de encontros diversos em busca da construção comunitária de uma dança ao encontro permanente dos sentidos para a vida pautados nos saberes tradicionais de povos e culturas do Brasil. Por meio de trocas vividas com a proposta metodológica do Jogo da Construção Poética' no âmbito das Universidades Federais do Rio Grande do Norte (UFRN), do Sul da Bahia (UFSB) e da Escola de Dança da UFBA apontamos para questionamentos significativos ao pensar, sentir e viver uma dança descentralizada, que propõe pesquisas em constantes transformações nascidas das vivencias, estudos e pensamentos críticos em contraponto à lógica de produção logocêntrica, meritocrática e subalternizante que caracteriza a ordem do modelo civilizacional vigente em grande parte do sistema educacional

Palavras chave: Dança; Saberes tradicionais; Poética, Ancestralidades

\section{ABSTRACT}

The poetic narrative of Lara Rodrigues Machado and Sebastião Silva offers the readers stories about life and/or scene experiences that unfold through many meetings in pursuit of the communitarian construction of a dance in the permanent encounter of the senses for life guided on the traditional set of knowledge of the peoples and cultures from Brazil. By means of exchanged living experiences with the methodological proposition of The Game of Poetic Construction in the sphere of the Federal Universities from Rio Grande do Norte (UFRN), from Sul da Bahia (UFSB) and from UFBA's dance school, we point to meaningful questionings when thinking, feeling and living a decentralized dance that proposes researches in constant transformations that are born from the livingness, studies and critical thoughts in counterpoint to the logic of logocentric, meritocratic and subalternizing production that characterizes the order of the civilizational model in effect in a large part of the educational system.

Key words: Dances, Traditional knowledge, Poetics and Ancestry 


\section{Andanças e Cheganças}

Essa narrativa poética foi construída em parceria afetiva, criativa e textual entre a artista pesquisadora Lara Rodrigues Machado e o artista pesquisador Sebastião Silva. Nessa narrativa encontraremos histórias de experiências contadas, cantadas e dançadas por personagens diversas da vida e ou da cena.

Nosso encontro desde sempre despertou o desejo de realizações contínuas de uma dança descentralizada de toda sua dureza e rigidez para a busca permanente daquilo que nos traz sentidos para a vida. Nossos textos se entrelaçam na medida em que vivenciamos a proposta metodológica do Jogo da Construção Poética i descrita no livro "Danças no Jogo Da Construção Poética". Lara como idealizadora da proposta em parceria com sua comunidade, e Sebastião Silva como aluno e intérprete de processos criativos. Processos estes, desenvolvidos em diálogos com Lara Rodrigues Machado no âmbito da Universidade Federal do Rio Grande do Norte, perpassando pela Universidade Federal do Sul da Bahia (UFSB) nos encontros de Poéticas e Ancestralidades, e finalmente no ano de 2020 nas relações diversas de orientação de doutorado na Escola de Dança da UFBA.

Nessas experiências, Sebastião tem a percepção interna e orgânica dos processos de criação artística; Lara tem a percepção de perto e integrada, mediada pelas trocas entre orientações e cenas constitutivas de uma verdadeira poética corporal. 
ISSN 2358-6060

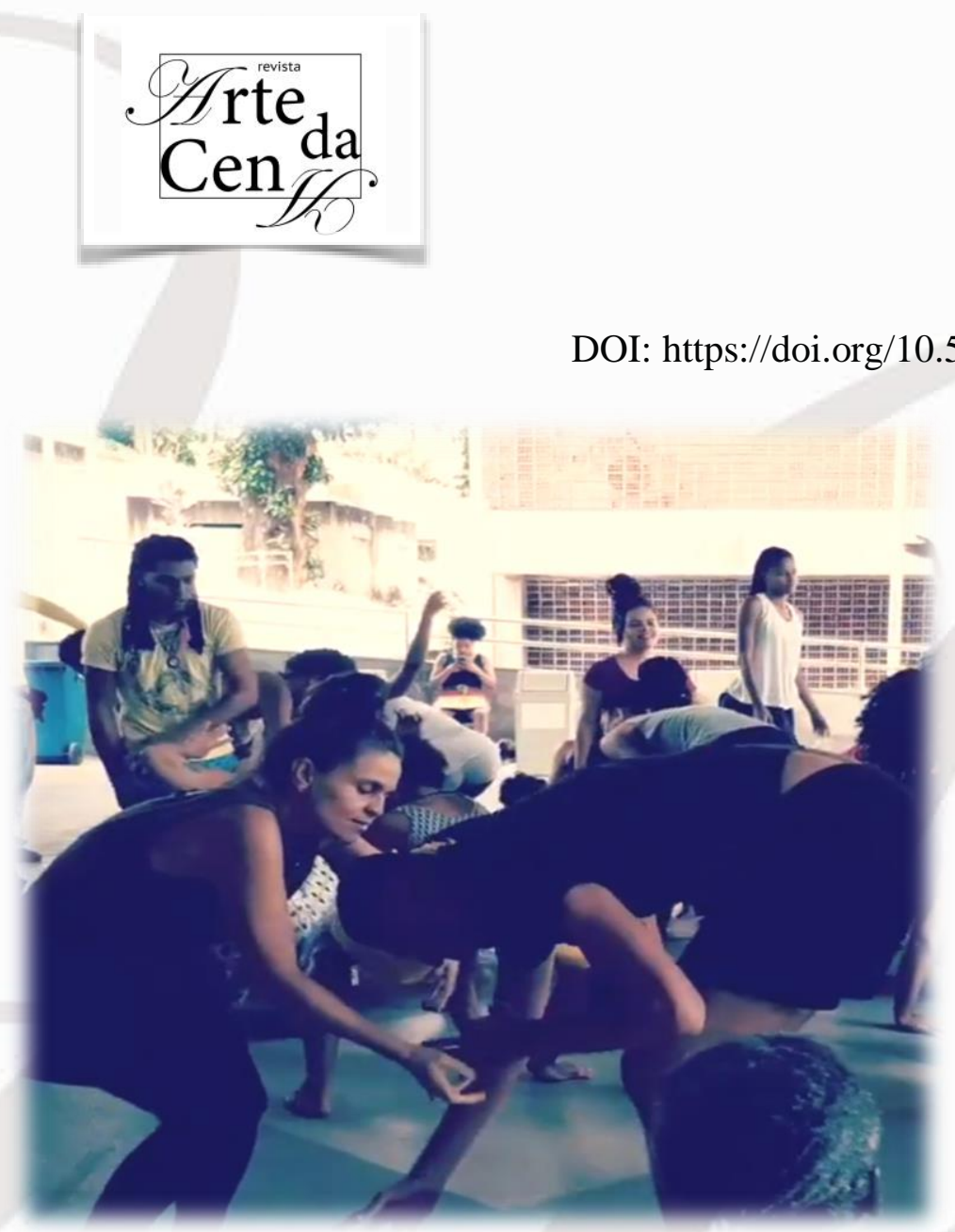

Fig. 1- Arquivo Pessoal. UFBA, 2019.

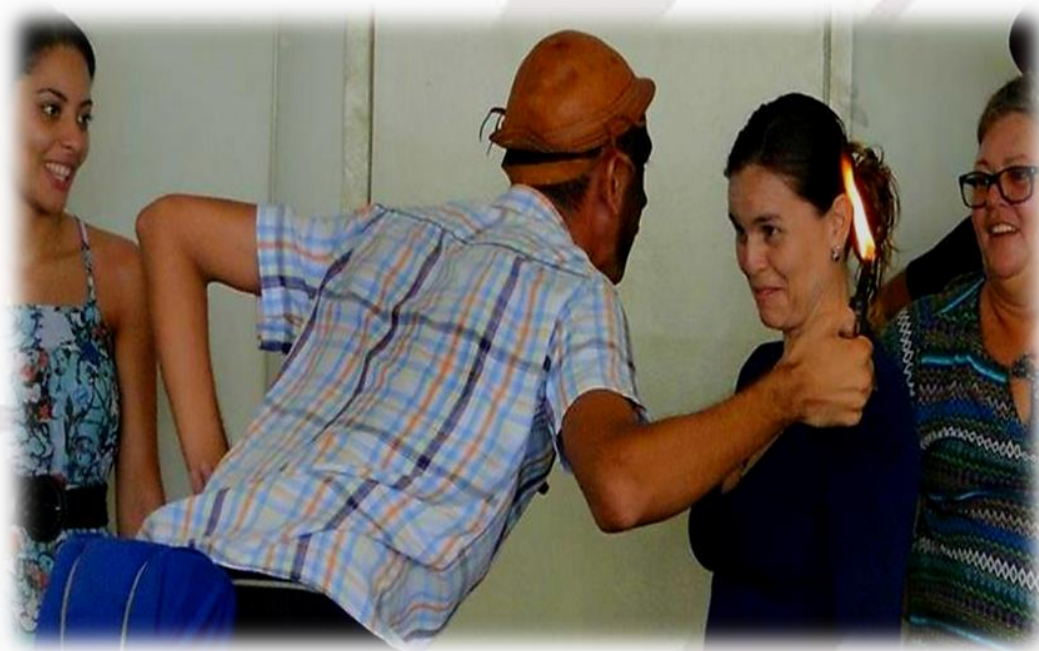

Fig. 2 - Arquivo Pessoal. UFRN, 2016.

Nas próximas linhas, serão descritas algumas vivências de Sebastião e de trocas com Lara, nas quais desejamos e esperamos aqui traduzi-las da melhor maneira, consentindo que isso que nos capturou e captura até os dias de hoje, também consiga estabelecer um diálogo por meio da palavra escrita.

Sebastião Silva, Lara Rodrigues Machado - Danças, poéticas e os saberes corporificados revista Arte da Cena, v.6, n.2, ago-dez/2020.

Disponível em http://www.revistas.ufg.br/index.php/artce 


\section{Tião e seus atravessamentos}

Imaginem um menino debaixo do vestido de sua mãe. Ele tem corpo alongado, olhos grandes, porém tímidos, tem medo de transver o mundo, de atravessar a rua sozinho e ser capturado pela pelas ciladas que escorrem das ruas do interior. Quem é do interior sabe: tem carro-preto que pega menino e leva para o papa figo ii; tem o velho do saco que engana menino dizendo que vai dar um presente e leva o menino para bem longe do seu aconchego familiar e tem ainda as estórias de Trancoso, estas são várias, desde do disco voador até o lobisomem em dia de lua cheia.

O menino dessa narrativa poética mora no Estado do Rio Grande do Norte, em uma cidadela com nome de Vera Cruz, especificamente na comunidade chamada pelos seus, de Sítio de Santa Cruz, sim, são algumas cruzes, Vera, Sítio e tantas outras que marcam as encruzilhadas desse menino que cresceu e que resolveu escrever sobre as suas histórias, memórias, ancestralidades e atravessamentos em forma de circo, teatro, dança, culturas populares e as brincadeiras que pulsam, respiram e formam esse corpo em estado dinâmico de ser e estar um ator-brincante. Esse menino tem nome, recebeu em homenagem ao seu avô paterno, o nome do guerreiro das matas - Sebastião; um menino com alma de gente velha, ancestral.

No primeiro momento, pedimos que imaginassem um menino debaixo do vestido de sua mãe... Agora, pedimos que imaginem dois senhores, um de nome tempo que está sentado debaixo de um cajueiro frondoso, bem verdinho e o outro nominado de silêncio, este corre por dentro do tempo e o coloca de pé para dançar - foi a partir desses dois senhores, o tempo e o silêncio que o menino resolveu sair debaixo do vestido da sua mãe para dançar as memórias atravessadas pelos seus. Tudo parecia não caber 
mais dentro dele. Olhava para o terreiro e as brincadeiras pareciam ter se esgotado... Adorava dançar com a chuva, sentia a própria tempestade agitada correndo pelas ruas de barro vermelho, devastando tudo que vinha pela frente, brincava e era brinquedo em sua comunidade; o menino cresceu, estudou, fez todas as etapas do ensino infantil, fundamental e médio por ali mesmo, mas ele nem imaginava que teria a oportunidade de entrar na universidade, pois o destino já tinha predestinado que aquela árvore que ali foi plantada, regada, crescida, por ali mesmo morreria. Mas não, tudo mudou quando ele descobriu que era capaz de voar, dançar, fazer arte e atravessar aquela placa verde do "seja bem-vindo a Vera Cruz". Sabe aquelas placas de boas-vindas que tem em todas as entradas e saídas das cidades? Pois bem, ele resolveu tentar a vida lá fora, fez a mala, colocou as poucas roupas que tinha, mas não esqueceu alguns e talvez os principais adereços, saudades, brincadeiras populares, circo, dança, teatro na escola, pastoril, Boi de Reis e muitas memórias atravessadas em seu corpo.

Contaremos algumas histórias dançadas no atravessar da ponte do interior do RN para as cidades grandes de Natal e Salvador. Entre as escrevivências ${ }^{\text {iii }}$ das artes traremos encangadas, as pedagogias, literaturas e culturas do RN, danças e as inúmeras cenas, deste corpo que descentraliza e margeia o seu fazer artístico.

Na valorização de nossas inúmeras personagens da cena e da vida, em meio aos Bois, Zés, recriações, infâncias, corpos, chamas, brincadeiras, memórias, as DANÇAS acolhem os estudos desse menino Sebastião desde a travessia pela ponte até sua chegança no Curso de Doutorado da Escola de Dança da UFBA.

O Mestrado realizado na UFRN homenageia o brincante de Boi de Reis - Zé de Moura em corpo cênico como uma poética dançada. O recorte 
na pesquisa se deu a partir do corpo de Zé de Moura (que dentro da brincadeira assumia a figura do Mateus). Tião viu Zé de Moura durante muitos anos dançar em frente à igreja de São Caetano na comunidade do Sítio de Santa Cruz; o menino se escondia entre um e outro com medo de ser pego e posto dentro da roda da brincadeira; mas ao mesmo tempo que ele temia, ele se encantava com a magia daquela brincadeira e foi atravessado pela dança de Zé de Moura. Tião passava por debaixo das pernas do público na tentativa de chegar o mais próximo do bailarino da rua. O menino dançava com os olhos para tentar acompanhar o trupicar dos pés do brincante que rodopiava feito o pião que Tião tinha em sua casa; Zé de Moura brincou com as memórias do menino, passeou pelo seu corpo, mapeou o seu imaginário popular.

O menino cresceu, estudou e quando adentrou o Mestrado em Artes Cênicas, resolveu recriar e dançar as memórias que povoava o seu corpo, ele dançou as fitas de seu terreiro; descortinou-se e descobriu que o corpo em estado de dança acessa uma profundidade que vai além daquilo que é desenhado perante o público. A dança permite ao intérprete viver em atravessamentos, e estes, afetam, ressignificam e encruzilham tanto aquele que vê como aquele que se põe a dançar.

A dissertação acadêmica de mestrado batizada de "Saudades Z(é): Metaforizando a construção do corpo brincante ${ }^{\prime i v}$, é uma pesquisa que fez referência às suas memórias de ator-pesquisador, entre as brincadeiras do Boi de Reis da comunidade do Sítio de Santa Cruz, da Cidade de Vera Cruz/RN.

É isso mesmo, a personagem Zé dançou com as memórias do menino Sebastião no corpo de ator-brincante que na infância se escondia debaixo do vestido de sua mãe. $O$ vestido que escondia o menino ganha o mundo 
dançando nesse corpo que carrega uma lamparina nas mãos, uma luz que esconde e revela as danças descentralizadas a partir da raiz de seu povo, de forma muito particular, as raízes ancestrais de suas avós, de sua mãe, de sua irmã e de sua sobrinha - mulheres que marcaram e marcam a tessitura desse menino brincante que se põe a dançar.

Ainda na travessia dessa ponte que leva o menino aos dias de hoje vivemos encontros de Poéticas e Ancestralidades organizados pala artista pesquisadora do campo de estudo das artes da cena, Lara Rodrigues Machado; a mulher que rodopiou sobre o corpo de Sebastião; que o levou a perceber quais danças advém de seu corpo, de seu povo, que o fez olhar para si. Juntos, construíram uma educação marcada no e pelo corpo que dança; realizaram uma travessia, uma pedagogia do corpo, onde a mestra trocou de papel com o aprendiz e vice-versa - foram muitas "quebras de joelhos", muitas trocas de olhares e um profundo silêncio que dançava no vazio, uma pedagogia de saberes, onde a professora e o aprendiz aprendiam juntos:

Foi a partir deste corpo emoldurado que a professora, rodopiando com a sua saia, passava por entre os seus alunos e dizia: - "quebra o joelho, vai" e tudo aquilo eu não entendia, não sabia o porquê de ela estar pedindo aquilo. Tudo se deflagrava quando escrevia meu diário de bordo, tinha realmente medos de deixar registradas as descobertas que tinham despertado - era um corpo habitado em mim e que eu mesmo não tinha conhecimento. (SILVA, 2020, p. 59).

Mais uma vez o silêncio tirava o tempo para dançar; e quando um estava de frente com o outro - cabeça com cabeça - de corpo inteiro, seus corpos pulsavam em poéticas e ancestralidades.

Esses encontros aconteceram durante os anos de 2012 a 2019, e neles Sebastião e Lara plantam sementes que foram cultivadas e se revivificam a cada ano. Todos os encontros são regados a uma troca infinita de saberes, as 
duas figuras desta dança, brincam sobre a terra de seus corpos como um bom agricultor e agricultora do sertão nordestino - que olham para o céu e veem no sol de suas cabeças quando o tempo está bom para plantar, fazer à limpa e colher o alimento de seus corpos, é um processo de retroalimentação com o Universo.

É uma troca que se dá por meio de uma dança que é descentralizada. Estamos chamando de dança descentralizada uma dança que é desenhada, pulsada a partir do nosso chão, dos nossos saberes, que muitas vezes são colocados à margem por não fazer parte das ditas danças como clássicas, que codificam o corpo com passos e coreografias marcadas/centradas, com códigos (que se repete da mesma maneira de um corpo para o outro), um código determinado, ensinado de uma pessoa para outra, sem perpassar pelas histórias, pelas corporeidades dos sujeitos, enquadrando-os em lugares que não nos cabem, pois estes corpos que aqui se inscrevem, eles pulsam, brincam e dançam suas histórias ancestrais em saberes tradicionais e populares.

Nessa brincadeira de uma escrita dançante narrativa, as danças descentralizadas perpassam por um fio interno que tem a ver com os sentidos, as percepções e as histórias dos indivíduos: que é a experiência corporificada. Tomamos como referências os nossos saberes populares e dançamos a partir de nossas histórias, memórias e atravessamentos ancestrais, quebramos os joelhos de um ideário centralizador e hegemônico da história da dança; colocamos na gira dos nossos corpos pulsantes escrevivências tanto de cunho biográfico quanto memorialístico, escrevemos e nos inscrevemos uma dança a partir dos nossos saberes populares, de processos que permitem a libertação do conhecimento e autonomia de um corpo que se poetiza no espaço-tempo, no qual, eles se metamorfoseiam e 
metaforicamente se aterram, sopram, choram e pegam fogo numa giraencruzilhada pela arte do dançar.

\section{O Jogo da Construção Poética}

A proposta metodológica do Jogo da Construção Poética idealizado por Lara Rodrigues Machado está focada na questão da identidade dos corpos, embasada nas pesquisas sobre os saberes tradicionais das culturas afro-indígenas e no processo artístico pedagógico das atividades cotidianas, por meio de práticas corporais, pesquisas de campo e laboratórios de interpretação que são seguidos pela elaboração criativa das cenas, até sua finalização em roteiros artísticos.

No livro "Danças no Jogo da Construção Poética" (MACHADO, 2017), apresentamos não apenas uma maneira de ser estar na vida e na cena, como contamos histórias diversas de vivências das comunidades envolvidas em processos dessa natureza. Dessa forma, buscamos agregar ao cenário acadêmico e artístico das artes do corpo um contributo capaz de refletir um processo cênico que mostre a abertura de expressões corporais e estabeleça pontes de aproximação entre histórias e culturas, revelando aspectos fundamentais da singularidade, subjetividade e alteridade na contemporaneidade.

Os trabalhos artísticos e de pesquisas realizados até o momento, com base na Proposta metodológica do Jogo da Construção Poética proporcionaram relações críticas e criativas ao experimentar diversas linguagens de expressão e ao aprofundar relações entre seus/suas participantes e as comunidades contempladas nos trabalhos de pesquisa artística e acadêmica que são ali apresentados. Esses mesmos trabalhos contribuíram também para fomentar discussões diante da escassa 
bibliografia e fomentar processos de criação no contexto acadêmico sobre conceitos estéticos e ideológicos alicerçados no universo das culturas e povos africanos, indígenas e na cultura popular brasileira. Tais estudos geraram resultados que, quando inseridos na prática docente, encontraram eco e ramificações em trabalhos acadêmicos e artísticos realizados ao longo dos últimos 20 anos.

Entre as lembranças que pulsam fortes nesse momento de 2020 algumas vividas nos Encontros de Poética e Ancestralidade ${ }^{v}$ a exemplo das conversas da filha de Paulo Feire, Fátima Freire Dowbor, com um menino atrevido e inquieto para compreender como a educação marca o corpo. Tião sonhou com esse encontro, ele nos dizia "minha nossa, vou me encontrar com a filha de Paulo Freire, acredito que vai ser maravilhoso". Era a noite de 12 de março de 2019, uma noite fria como muitas no Sul da Bahia, na cidade de Porto Seguro, no entanto, uma noite especial para todos os envolvidos, pois a UFSB concedia o título de menção honrosa ao educador e patrono da educação, o professor Paulo Freire. O auditório da UFSB estava organizado em semi-arena, todos(as) ansiosos(as) por aquele momento.

Tião sentou na frente para não perder nenhuma palavra proferida pela palestrante. Ela apresentou o seu livro "Quem educa marca o corpo do outro" (2008) e prosseguiu a palestra diferenciando os tipos de plateia 'há aqueles que perguntam por não saber e há aqueles que perguntam para assumir o lugar do palestrante' - o menino que além de ser marcado pela arte, é também marcado pela pedagogia em sua formação primeira. A explicação mexeu com o corpo de Tião, ele com um corpo de 1,94m se mexia e não conseguiu esconder o desconforto provocado pela condução da 'filha do professor'; ele dançava na cadeira para um lado e para o outro, uma inquietude sem fim, uma dança que não tem nome, desejou levantar e sair da 
cena, mas a palestrante resolveu desafiá-lo para uma dança a dois - ela vinha a sua frente como um boi solto para pegar o vaqueiro no pasto; ele não hesitou! Quando ela perguntou:

"Você não está entendendo nada? Deseja falar algo?".

O menino dançou com os olhos em direção à professora Lara como se pedisse permissão, ela dançou com o sorriso e disse: Sim! Ele atravessou-se e pôs-se a dançar com as palavras, disse o seu nome, o nome de sua mãe Janilda e do seu pai Francisco, falou de sua comunidade, Sítio de Santa Cruz e olhou para a plateia fazendo o convite para que todas as vezes que tivéssemos a oportunidade de falar, que falássemos a partir das nossas raízes, das nossas poéticas e ancestralidades. Dalí as inquietações se transformaram em continuidade num ciclo de poéticas, inúmeras dúvidas, nenhuma certeza, e um despertar para o outro. Nessas giras e trocas persistimos na busca de ir além, no desejo de ser afetado e afetar, na percepção dos giros sobre nós mesmo.

\section{Serestar Catirina}

Atualmente o menino Tião tem 31 anos e com a passagem do senhor Tempo, o senhor Silêncio não é mais o mesmo! Ele resolveu sair para passear e talvez jamais retornar... Por um instante sobre a tela da janela, olha para as nuvens e se vê dançando; algumas imagens se revelam como uma fotografia pendurada em uma parede, mas na parede ficam apenas as molduras, pois a sua dança não cabe dentro de uma caixinha, ela vai além... O menino homem recria o Tempo e deixa o silêncio gritar. Os ruídos são muitos e trazem imagens que pulsam, dançam e brincam com as memórias. O corpo vibra! E tudo é vibração, fantasia e recriação. 
Um sonho e uma escolha tomam o corpo desse menino homem: fazer uma seleção para o doutorado em dança. Era a dança que chamava, era Catirina, outra personagem assumindo a cena ao fazer o seu corpo tremer, ficar em chamas e queimar. É a vez de Catirina fazer a gira girar, conhecer a Bahia, com a mala mais uma vez cheia de saudades e tantos outros adereços que ainda serão revelados, atravessou de um lugar a outro e parece que o menino não quer mais voltar, ele já não é mais o mesmo, seu corpo foi marcado e implicado sobre tantas questões.

Na Escola de Dança da UFBA apresentou seu projeto "Serestar Catirina: Atravessamentos no corpo do ator-brincante". Um corpo que tenta rememorar as suas narrativas com o universo da brincadeira, especificamente com a brincadeira do Boi de Reis da Cidade de Vera Cruz/RN como uma representação cultural de um povo, da brincadeira no corpo da personagem Catirina.

A proposição de pesquisa torna-se um mergulho no avesso do avesso dos nossos corpos enquanto intérpretes-criadores que implica no contexto sociocultural da brincadeira do Boi de Reis. Um corpo que se metamorfoseia, um ator-brincante que dança as memórias do seu povo, que faz de sua dança um grito manifesto, que se revela na cena e que se questiona: Mas, afinal quem é a Catirina? Ela é a companheira do Mateus (figura que cuida dos Bois da fazenda. Ela está grávida e deseja comer a língua do Boi mais bonito), ela grita e rasga o seu desejo: "Mateuuus, EU QUERO COMER A LÍNGUA DO BOI"!

O desejo de Catirina anuncia a chegada da morte na brincadeira, pois o desejo de uma mulher grávida deve ser atendido, mas este ato não se justifica pelo fato dela estar grávida, mas sim pelo ciclo da vida/morte. É neste momento em que o Boi mais bonito da fazenda, o "filho" do dono das 
terras, do patrão, do Mestre será sacrificado, crucificado, expiado, ofertado em salvação dos pecados de Mateus, para atender o desejo de sua companheira, que não pode deixar o seu filho nascer com a cara de Boi. Nesse momento, é preciso matar para dar vida à outra vida.

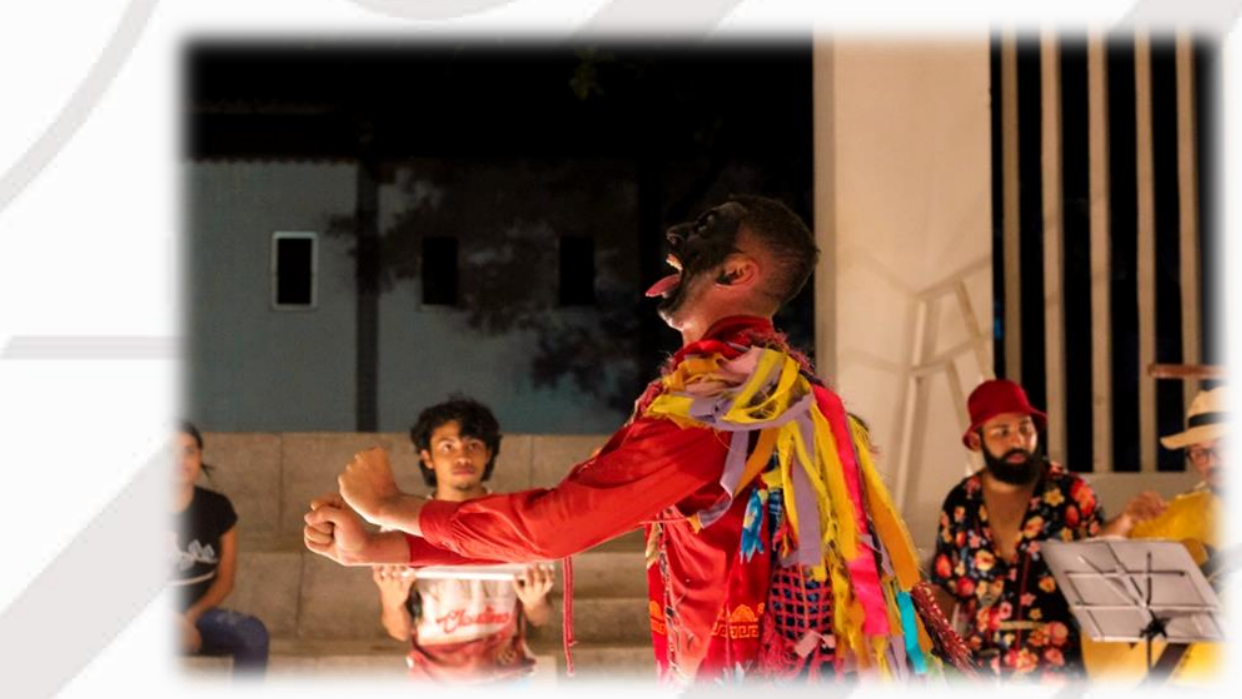

Fig. 3 - Espetáculo Saudades Z(é). Foto: João Vítor Venâncio, 2020.

O que apresentamos aqui são implicações políticas e educacionais que se apagam e se revelam nesse processo de criação, nessa dramaturgia que dança a recriação do imaginário popular; são questões de ordem pessoal e que se universalizam; quantas vezes morremos perante a sociedade? Quantos corpos estão engendrados por padrões estéticos e discursos do tipo "o corpo da mulher é isso, o do homem é aquilo".

...pois bem, atravesso-me simbolicamente na figura de Catirina e me pergunto: quantas vezes será preciso pedir o "corpolíngua" deste Boi que aqui escreve para justificar esse corpo masculino que tem traços, marcas e tessituras femininas? Essa pesquisa é um desvelar de mim mesmo e coloco a lamparina na mão de Catirina pedindo-a que ela me alumie e me revele nesse corpo que brinca, que dança e que me coloca em atravessamentos, em trânsitos de serestar Catirina. (Sebastião Silva, 2019).

Sebastião Silva, Lara Rodrigues Machado - Danças, poéticas e os saberes corporificados 
Nessa pesquisa, a proposta metodológica do Jogo da Construção Poética (MACHADO, 2017) atrelado a ideia de Corpo e Ancestralidade (SANTOS, 2002), irá ciceronear a dança por meio das investigações artísticas e das memórias da personagem Catirina no corpo do ator-brincante.

O Jogo da Construção Poética por meio de trocas de experiências e estudos referentes a rituais, às formas de comunicação tradicionais, aos processos de criação e experiências estéticas em diálogo com a oralidade, memória e cultura brasileira busca contribuir com as linguagens cênicas na contemporaneidade. Através do Jogo da Construção Poética, acreditamos estar oportunizando um descortinar dessas pesquisas que incorporam a pluralidade cultural brasileira, por meio das histórias individuais e dos movimentos tradutórios encontrados nas mais diversas manifestações populares por todo o país.

Percebemos durante essa caminhada de realizações até o presente momento (2020), que as orientações de iniciação científica, mestrado e doutorado têm sido uma recuperação de fios, conscientes e inconscientes que se aprimoram e se aprofundam, dando possibilidades de novos relevos nesta trama compartilhada. Dessa forma, a partir de uma concepção filosófica de enfocar a Cultura na criação artística, com a natureza humana, a tradição e história de cada um, pela via da dança, do canto, das imagens, as orientações desdobram-se na realidade de cada orientado no contexto da contemporaneidade.

Nos últimos doze anos, vivenciamos processos artísticos pedagógicos em torno do Jogo da Construção Poética, na busca de aflorar as percepções corporais de cada pessoa envolvida nesse trabalho: "O ato de se preparar para receber o outro revela como anda o processo de internalização desse 
outro em meu corpo. Ou seja, revela como eu tenho o outro dentro de mim" (DOWBOR, 2008).

Com isso acreditamos nas relações desenvolvidas durante todo o processo criativo de pesquisa em arte como alicerce. Principalmente quando escolhemos as pesquisas de campo impulsionadoras desses diferentes processos e vivências.

Os guardiões do modelo da cultura popular encontramse principalmente entre os peões, os boias frias, os lixeiros, os caminhoneiros, as cozinheiras, os tratoristas - enfim, nos grupos de gente simples e humilde que tem o poder de transformar um cotidiano duro e sofrido numa celebração da vida. (RODRIGUES, 1997, p. 125).

Pra nós, no processo do Jogo da Construção Poética, o corpo está não apenas diretamente implicado, mas colocado em primeiro plano, de modo a despertar entendimentos que apontem caminhos alternativos perante as crises que vivemos, contemplando as subjetividades assentadas na memória cultural, dessa vez corporificada. Com a intenção de reafirmar os saberes populares, as práticas, os valores e conhecimentos assentados na ancestralidade em suas poéticas próprias, as pesquisas fruto desses processos desenvolvidos com base no Jogo da Construção Poética, proporcionaram trocas de saberes que são encarnados, produzidos pelo corpo e com o corpo.

Estes processos e vivências proporcionaram, ainda, indagações em múltiplas dimensões sobre o que pode ser uma subjetividade que acolha a memória cultural dos saberes africanos e indígenas, com suas formas de conhecimento, visões de mundo e cultura contra-hegemônica. 


\section{Poética e Ancestralidade}

Em nossos encontros de Poética e Ancestralidade escolhemos a roda como importante forma de acontecimento, assumindo que não há como produzir conhecimento sobre determinadas práticas da cultura sem sermos afetados por suas próprias consistências. Tanto as pesquisas investigativas para a cena, como os processos constituídos de rodas de conversa, rodas de danças e rodas de práticas diversas, têm como um de seus objetivos a dialogicidade e força integradora. Assumindo o corpo como fio condutor e produtor do conhecimento, ao celebrar os Povos, as Culturas Brasileiras, as Poéticas e a Ancestralidade, no encontro da comunidade acadêmica com comunidades de saberes tradicionais, potencializam-se desdobramentos, a exemplo das poéticas em suportes variados e as práticas que criam o corpo da cena, as pedagogias e a interdisciplinaridade inerente aos saberes tradicionais africanos e indígenas.

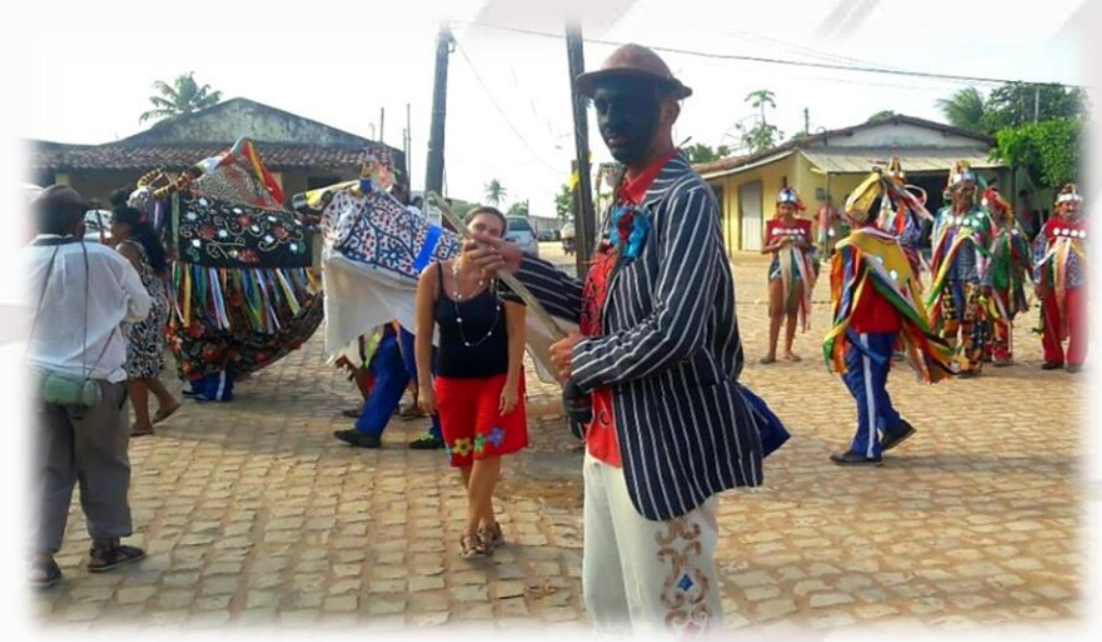

Fig. 4-Chegança para o espetáculo Saudades Z(é). Acervo pessoal, 2017.

Buscamos oferecer dentro da academia um contraponto à lógica de produção logocêntrica, meritocrática e subalternizante que caracteriza a ordem do modelo civilizacional vigente em grande parte do sistema 
educacional. Acreditamos que essa busca só se faz possível por meio do corpo, enquanto campo de possibilidades, produtor de conhecimento, de saber e memória, que reinventa a vida e ressalta suas potências.

Na busca de construir parcerias diversas, que nos ajudem a ultrapassar limites, que nos amparem o olhar para enxergar além, além de nós, além de tudo, criamos relações, que se recriam e alimentam-se. Falamos aqui de uma Dança para antes e depois do corpo físico. Dança da espiritualidade para um eterno recomeço. No encontro de mundos em que nos percebemos, seguimos na busca de encontrar-se a si mesmo para encontrar o outro, para estar no mundo e transcender.

Acreditamos no coletivo, em nossas comunidades, é isso o que nos proporciona compreensão de mundo. Percebemos corpos a inspirarem-se sempre no espaço no tempo como água em vapor, na criação de mundos de cenas, de sonhos, flexíveis, generosos e amáveis.

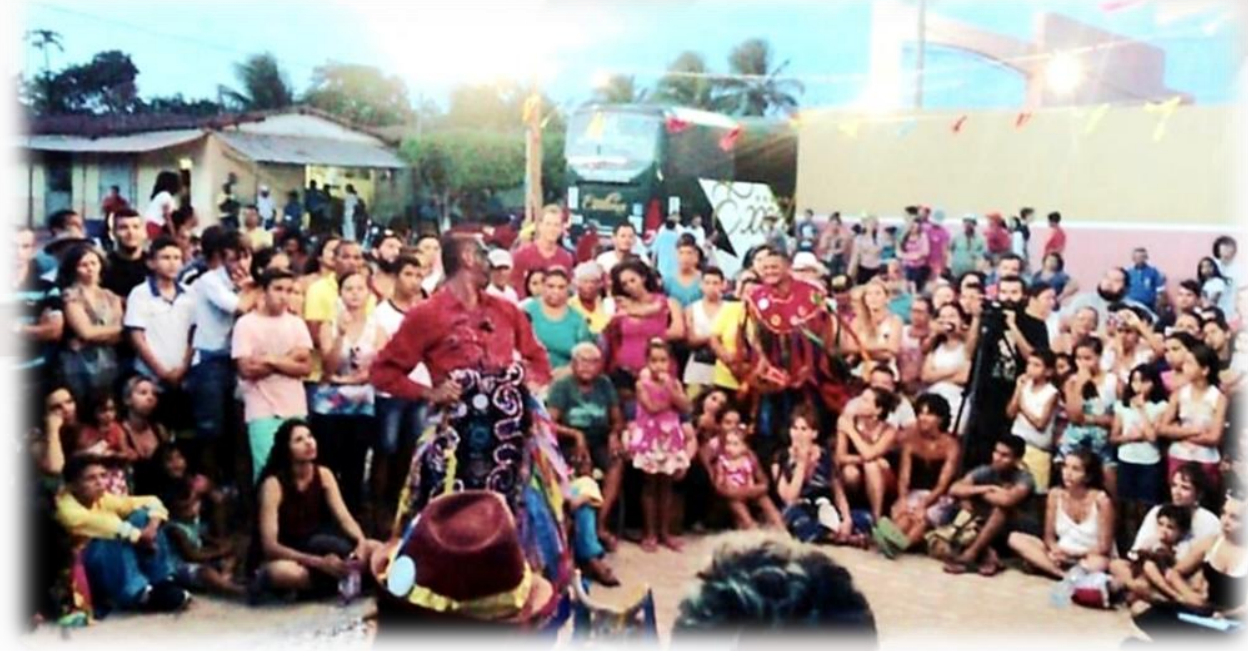

Fig. 5- Catirina no espetáculo Saudades Z(é). Acervo pessoal, 2017.

Por fim, no desejo de que muitos corpos, personagens e histórias venham nos ajudar a descentralizar a dança que nos habita e que promove a 
continuidade de trocas entre nós, deixamos rastros de vivências compartilhadas em artes e saberes inacabados de nossos contínuos estudos.

\section{REFERÊNCIAS}

DOWBOR, Fátima Freire. Quem educa marca o corpo do outro. São Paulo: Cortez, 2008.

MACHADO, Lara Rodrigues. ANDRADE, Sara Maria de. (Org.). Danças no Jogo da Construção Poética. $1^{\mathrm{a}}$. ed. Natal: Jovens Escribas, 2017, 188p.

MACHADO, Lara., DOMENICI, Eloisa., RODRIGUES, Éder., (org.). Corpo, Poética e Ancestralidade. Salvador, v. 23, n. 42, p. 01-245, 11 mar. 2019. Semestral. Disponível em: http://www.ppgac.tea.ufba.br/wpcontent/uploads/2019/0g/cad gipe cit-42.pdf http://www.ppgac.tea.ufba.br/wp-content/uploads/2019/og/cad_gipe_cit42.pdf. Acesso em: 14 ago. 2020.

RODRIGUES, Graziela Estela Fonseca. Bailarino-pesquisador-intérprete: processo de formação. Rio de Janeiro: FUNARTE, 1997.

SANTOS, Inaicyra F. dos. Corpo e ancestralidade: uma proposta pluricultural de dança arte e educação. São Paulo: Editora Terceira Margem, 2006.

SILVA de Oliveira, Luiz Henrique Reseña de "Becos da memória" de Conceição EVARISTO. Revista Estudos Feministas, vol. 17, núm. 2, maioagosto, 2009, p. 621-623. Universidade Federal de Santa Catarina - Santa Catarina, Brasil.

SILVA, Sebastião de Sales. A ancestralidade do corpo: diálogo com os mestres. Revista Manzuá, vol. 3, núm. 1, 2020. p. 56-79. Programa de PósGraduação em Artes Cênicas - UFRN/DEART/CCHLA.

Saudades Z(é): metaforizando a construção do corpo brincante. 2017. 10of. Dissertação (Mestrado em Artes Cênicas) - Centro de Ciências Humanas, Letras e Artes, Universidade Federal do Rio Grande do Norte, Natal, 2017. 


\section{NOTAS}

' MACHADO, Lara Rodrigues. ANDRADE, Sara Maria de. (Org.). Danças no Jogo da Construção Poética. $1^{\text {a }}$. ed. Natal: Jovens Escribas, 2017, 188p.

ii Entende-se por papa figo uma figura do imaginário popular do Agreste Potiguar, descrito e caracterizado como um homem velho que anda todo maltrapilha, com roupas sujas e rasgadas e com um saco na mão, nominado também como 'o velho do saco' que retira o fígado das criancinhas para vender e/ou comer.

iii [...] De corte tanto biográfico quanto memorialístico, nota-se o que a autora chama de escrevivência, ou seja, a escrita de um corpo, de uma condição, de uma experiência negra no Brasil. A obra se constrói, então, a partir de "rastros" fornecidos por aqueles três elementos formadores da escrevivência: corpo, condição e experiência. (Disponível em: https://www.redalyc.org/pdf/381/38114362019.pdf. Acessado em: 14 de agosto de 2020.

iv Disponível em: https://repositorio.ufrn.br/jspui/handle/123456789/22628. Acessado em: 14 de agosto de 2020.

${ }^{\vee}$ Os encontros (2015 -2019) abrem indagações em múltiplas dimensões sobre o que pode ser uma subjetividade que acolha a memória cultural e os saberes africanos e indígenas, com suas formas de conhecimento, visões de mundo e cultura contra-hegemônica. Assumindo a crise atual da subjetividade, os participantes do evento Corpo, Poética e Ancestralidade se reencontram e subvertem a convergência de crises, construindo espaços de resistência. Nestes encontros o corpo está não só diretamente implicado, mas colocado em primeiro plano, contemplado de maneira especial nas atividades que intentam proporcionar relações críticas e criativas ao experimentar diversas linguagens de expressão e o aprofundamento de relações entre as comunidades articuladas a trabalhos de pesquisa e produção de conhecimento. O intuito é o despertar de entendimentos que apontem caminhos alternativos as crises que vivemos, ao contemplar as subjetividades assentadas na memória cultural, corporificada.

Sebastião Silva, Lara Rodrigues Machado - Danças, poéticas e os saberes corporificados revista Arte da Cena, v.6, n.2, ago-dez/2020. 
Interior do Coletivo de Atores $\mathrm{O}$ de casa, ô de fora, no qual assume a função de diretor e ator do Coletivo. Sebastião Silva tem em sua formação uma proposta multidisciplinar; é pedagogo e literato em culturas do Rio Grande do Norte. Atualmente faz o doutorado em Dança na Universidade Federal da Bahia (UFBA), na qual, integra o Grupo Interdisciplinar de Pesquisa e Extensão em Contemporaneidade, Imaginário e Teatralidade (GIPE/UFBA). Tião Silva é um menino, um brincante que resolveu fazer da sua arte o seu sacerdócio, vivendo em constantes atravessamentos.

**Lara Rodrigues Machado, graduada em Dança (1994), com Mestrado (2001) e Doutorado (2008) em Artes Cênicas pela Universidade Estadual de Campinas/SP (Unicamp). Professora Associada do Centro de Artes da Universidade Federal do Sul da Bahia (UFSB). Professora Colaboradora do Programa de Pósgraduação em Dança da Universidade Federal da Bahia (UFBA). Professora Colaboradora do Programa de Pósgraduação do Departamento de Artes da Universidade Federal do Rio Grande do Norte (UFRN). Líder do Grupo Interinstitucional de Pesquisa "Corpo e Ancestralidade" (UFBA). Pesquisadora do Grupo de Pesquisa "Poéticas do Corpo e Saberes Populares" (UFSB). Mestra pela Escola Brasileira de Capoeira. Área de interesse e atuação nos temas dança, cultura, sociedade, arte e capoeira.

Submissão: 19/08/2020

Aprovação:14/12/2020

Sebastião Silva, Lara Rodrigues Machado - Danças, poéticas e os saberes corporificados 